\title{
NEW WEST AMERICAN MARINE MOLLUSKS
}

\author{
By Paul Bartsch \\ Curator of Mollusks, United States National Museum
}

Among the many lots of minute marine mollusks sent to the United States National Museum for determination from time to time, there have been found quite a number of new species which are here described. Brief descriptions of a few of these, but not figures, have been published in the Journal of the Washington Academy of Sciences and in the Proceedings of the Biological Society of Washington, as cited under these species.

We are much indebted for this additional knowledge of new west American species, as well as for much additional information on species previously described, to a number of ardent collectors of mollusks.

The greatest number of those here described were collected by Dr. R. H. Tremper, who secured no less than seven undescribed species in a visit to San Clemente Island, as follows:

Astyris clementensis.

Opalia tremperi.

Aclis californica.

Odostomia (Chrysallida) tremperi.

Odostomia (Chrysallida) clementensis.

Odostomia (Evalea) bachia.

?Rissoella californica.

He also discovered Turbonilla (Mormula) enna and Odostomia (Salassia) oena off Dead Mans Island, California.

An exceedingly interesting sending came from Mr. Walter J. Fyerdam, whose material was collected in Shuyak Strait, Afognak Island, Alaska. From this sending I describe:

Turbonilla (Pyrgolampros) stelleri.

Turbonilla (Pyrgolampros) shayakensis.

Turbonilla (Pyrgolampros) middendorff.

Turbonilla (Pyrgolampros) eyerdami.

Odostomia (Evalea) eyerdami.

Alvania dalli.

No. 2660.-Proceedings U. S. National Museum, Vol. 70, Art. II

$20441-27-1$ 
Dr. I. S. Oldroyd, as usual, has contributed a large part of the species here described:

Melanella (Melanella) portlandica from Portland, Oregon.

Odostomia (Chrysallida) cumshewaensis from $\mathrm{Cu} \mathrm{m} \mathrm{sh}$ e w a Inlet.

Cerithiopsis (Cerithiopsidella) fia from Monterey, California. Vitrinella (Docomphala) columbiana from Departure Bay.

Dr. Carl C. Engberg's careful collecting about Friday Harbor, San Juan Island, and Olga, Washington, has brought to light large series of previously rare species as well as a large number of new species. They are:

Odostomia (Amaura) sanjuanensis.

Odostomia (Amaura) washingtona.

Alvania sanjuanensis.

To Mr. A. G. Smith we owe the discovery of-

Turbonilla (Pyrgolampros) ilfa at San Pedro.

Turbonilla (Pyrgiscus) delmontensis at Del Monte.

Margarites (? Lirularia) smithi at Monterey.

Vitrinella smithi at Whites Point.

A. M. Strong and C. E. White have, through their careful study of the habitats occupied by mollusks, made some splendid contributions to molluscan ecology in an old territory. Their work shows plainly that most of the fascinating field studies of mollusks and their adjustments to suitable habitats have scarcely been touched. We hope sincerely that they may continue their researches in this much-neglected field. To them we owe the discovery of-

Odostomia (Chrysallida) catalinensis at Catalina Island.

Odostomia (Evalea) strongi at Catalina Island.

Odostomia (Evalea) whitei at Point Firmin.

Our indefatigable friend Mr. C. R. Orcutt has added:

Turbonilla (Ptycheulimella) magdalenensis and

Odostomia (Chrysallida) era from Magdalena Bay.

Odostomia (Chrysallida) fia from Todos Santos, Lower California.

To each of the following we are indebted for a new species: Mrs. Carrie L. Simons, Amphithalamus stephensae from Magdalena Bay, Lower California; Mr. E. P. Chace, Odostomia (Chrysallida) chacei from off Cayucas, California; and the late Mr. Delos Arnold for Solariorbis arnoldi from San Pedro.

\section{ASTYRIS CLEMENTENSIS, new species}

Plate 1, fig. 5

Shell very small, elongate-ovate. Nuclear whorls flesh colored. Postnuclear turns yellowish horn colored with various zigzag mark- 
ings and fulgurations of brown. Nuclear whorls smooth. Postnuclear whorls appressed at the summit, marked by very fine lines of growth which are almost vertical, and numerous, closely spaced, microscopic spiral striations. Suture very slightly constricted Periphery of the last whorl well rounded. Base long, moderately rounded; columella marked by eight feebly developed spiral cords. Aperture large; posterior angle acute, decidedly channeled anteriorly; outer lip thin showing the external markings within; inner lip sinuous; parietal wall covered with a thin callus.

The type, Cat. No. 362456, U.S.N.M., was collected by Dr. R. H. Tremper on rocks at San Clemente Island, California. It has five and one-half whorls and measures, length, $3.2 \mathrm{~mm}$.; diameter, $1.5 \mathrm{~mm}$.

A topotype is in Doctor Tremper's collection. Cat. No. 211060, U.S.N.M., also contains one collected by S. A. L. Brannan on Catalina Island.

This species is nearest related to Astyris aurantiaca Dall, but is uniformly smaller.

OPALIA TREMPERI, new species

Plate 1, fig. 8

Shell moderately large, milk white. Nuclear whorls decollated. Postnuclear whorls marked by poorly developed, retractively slanting axial ribs which terminate at the summit in a series of cusps. Several ribs frequently fuse to form a single cusp. The ribs on the first two turns of the type are obsolete, on the third 20 are present, while the fourth has 22 , the fifth 24 , the sixth and last have 26 . In addition to the axial sculpture there are also obsolete varices at irregular intervals. The entire surface of the spire is marked by narrow spiral cords. The spaces that separate these cords are crossed by numerous, very slender, axial threads which give them a decidedly pitted appearance. Suture slightly constricted. Periphery of the last whorl well rounded. Base rather attenuated, marked by the continuations of the axial ribs and the same type of spiral sculpture described for the spire. Aperture large, decidedly oval, with a strongly expanded and thickened peristome; outer lip evenly curved; inner lip almost straight and continuing as a heavy callus over the parietal wall which renders the peritreme complete.

The type, Cat. No. 362454, U.S.N.M., was collected by Dr. R. H. Tremper on rocks at San Clemente Island, California. It has seven and one-half whorls and measures, length, $7.8 \mathrm{~mm}$.; diameter, $2.5 \mathrm{~mm}$. 
MELANELLA (MELANELLA) PORTLANDiCA, new species

Plate 1, fig. 6

Shell of moderate size, regularly elongate-conic, milk white, shining. Nuclear whorls decollated in the type. Postnuclear whorls narrow between the summit and suture with the summit appressed, very slightly rounded, marked at irregular intervals by varicial impressions. Suture only very slightly impressed. Periphery of the last whorl slightly inflated, strongly rounded. Base very short, strongly rounded. Aperture small, pyriform, oblique; posterior angle acute; peristome very much thickened; columella short, almost straight, decidedly thickened and reflected over the umbilical area as a thick callus; parietal wall covered by a thick callus.

The type, Cat. No. 362492, U.S.N.M., was donated by Mrs. I. S. Oldroyd and was collected at Portland, Oregon. It has 11.3 whorls and measures, length, $9.1 \mathrm{~mm}$; diameter, $3.1 \mathrm{~mm}$.

The short thickened aperture and short base will at once distinguish this from Melanella micans. There is a suggestion of Melanella (Balcis) thersites but its straight form and general proportions differentiates it from that species.

\section{ACLIS CALIFORNICA, new species}

Plate 1, fig. 2

Shell small, pupiform, thin, bluish white. Nuclear whorls not differentiated from the postnuclear turns. All the whorls well rounded, appressed at the summit which is finely crenulated, the rest marked by fine lines of growth which are somewhat retractively slanting. The type is slightly worn and shows no indication of spiral sculpture. Sutures moderately constricted. Periphery of the last whorl inflated and strongly rounded. Base short, strongly rounded narrowly umbilicated, marked like the spire. Aperture subquadrate; posterior angle decidedly obtuse; outer lip thin; columella almost straight, reflected over and appressed to the base for its posterior fifth; parietal wall covered with a thin callus.

The type, Cat. No. 362455, U.S.N.M., was collected by Dr. R. H. Tremper on rocks at San Clemente Island. It has six whorls and measures, length $5 \mathrm{~mm}$., diameter, $2.1 \mathrm{~mm}$.

TURBONILLA (PTYCHEULIMELLA) MAGDALINENSIS, new species

Plate 1, fig. 7

Shell elongate conic, bluish white. Nuclear whorls decollated in all our specimens. Postnuclear whorls very narrowly shouldered at the summit, flattened, somewhat contracted near the suture, marked by incremental lines and occasional indications of obsolete protrac- 
tively slanting riblets. The entire surface of the spire is marked, also, by exceedingly fine closely spaced incised spiral lines. Periphery of the last whorl well rounded. Base short, well rounded, marked by rather strong incremental lines and the same fine spiral sculpture that marks the spire. Aperture oval; posterior angle acute; outer lips thin; inner lip somewhat sinuous, slanting protractively, reflected over and appressed to the base for two-thirds of its length; parietal wall covered by a thin callus.

The type, Cat. No. 217930, U.S.N.M., was collected in Magdalena Bay, Lower California, by C. R. Orcutt. It has 111/2 whorls remaining and measures, altitude, $7.4 \mathrm{~mm}$.; diameter, $1.8 \mathrm{~mm}$.

Cat. No. 363779, U.S.N.M., contains nine topotypes.

TURBONILLA (STRIOTURBONILLA) KINCAIDI Bartsch

Plate 1, fig. 3

Turbonilla (Strioturbonilla) kincaidi Bartsch, Proc. Biol. Soc. Washington, vol. 34, 1921, pp. 33-34.

Shell rather broadly elongate conic, yellowish white. Nuclear whorls decollated. The remaining turns are moderately well rounded and somewhat overhanging, appressed at the summit, decidedly constricted at the suture, marked by rather depressed, slightly retractively slanting axial ribs, of which 18 occur upon the first of the remaining turns, and 20 upon all the other turns. The spaces which separate the ribs are moderately impressed and terminate roundly about one-eighth of the distance between the summit and the suture, anterior to the suture. Periphery of the last whorl well rounded. Base short, inflated, well rounded, marked by the feeble continuation of the axial ribs, which become evanescent before reaching the umbilicus. In addition to the above sculpture the entire surface of the spire and base is marked by very fine closely spaced spiral striations. Aperture rather large, very broadly oval, almost subquadrate; posterior angle obtuse; outer lip thin, showing the external sculpture within; inner lip slender, somewhat sinuous, reflected over and appressed to the base for three-fourths of its length; parietal wall covered by a moderately thick callus.

The type, Cat. No. 340844, U.S.N.M., comes from Dogfish Bay, Puget Sound. It has eight whorls remaining and measures, length, $5.5 \mathrm{~mm}$.; diameter, $1.7 \mathrm{~mm}$.

\section{TURBONILLA (CHEMNITZIA) ENGBERGI Bartsch}

Plate 1, fig. 4

Turbonilla (Chemnitzia) engbergi Bartsch, Journ. Wash. Acad. Sci., vol. 10, 1920 No. 20, p. 570.

Shell small, elongate-conic, thin, semitransparent, bluish white. Nuclear whorls decollated. Postnuclear whorls moderately rounded, 
appressed at the summit, marked by broad, slightly protractively slanting axial ribs, of which 14 occur upon all of the remaining turns, except the last, on which there are 16 . These ribs are a little broader than the spaces that separate them, and they become slightly flattened and weaker toward the summit. The intercostal spaces are deeply depressed pits, which terminate somewhat posterior to the summit of the succeeding turn, leaving a broad, smooth band at the suture. Suture strongly constricted. Periphery of the last whorl well rounded, not crossed by the strong axial ribs. Base short, well rounded, marked by incremental lines only. Aperture subquadrate, posterior angle obtuse; outer lip thin; inner lip slightly sinuous, decidedly obliquely inserted, the inner edge having a decidedly protractive slant; parietal wall devoid of callus.

The type, Cat. No. 334489, U.S.N.M., was collected by Dr. C. C. Engberg at San Juan Island, in the Gulf of Georgia. It has almost eight whorls remaining and measures, altitude, $3.7 \mathrm{~mm}$.; diameter, $1.1 \mathrm{~mm}$. Cat. No. 363782, U.S.N.M., contains a paratype from the same source. Four additional specimens from the same station are in Doctor Engberg's collection.

Cat. No. 347292, U.S.N.M., contains a specimen collected by Doctor Engberg in Friday Harbor, Washington, and Cat. No. 340866, U.S.N.M., contains 8 specimens from Washington without specific locality, also from Doctor Engberg; 10 more from the same station are in the Engberg collection.

This species occurs considerably farther north than any heretofore known Chemnitzia.

TURBONILLA (PRYGOLAMPROS) STELLERI, new species

Plate 2, fig. 4

Shell very regularly elongate-conic, flesh colored, with a broad zone of pale brown which extends from a little anterior to the periphery on the base posteriorly over half of the whorl. Nuclear whorls decollated. Postnuclear whorls appressed at the summit, which is very narrowly shouldered, decidedly flattened in the middle, and moderately constricted at the suture, marked by very regular, vertical axial ribs, of which 16 occur upon all but the last two turns, on which 18 are present. These ribs are about as wide as the spaces that separate them, on the first three turns; on the middle turns they are only half as wide, while on the last turn the intercostal spaces are about one and one-half times as wide as the ribs. In addition to the axial ribs the whorls are marked by fine lines of growth and numerous, very closely spaced spiral striations, which extend over both ribs and intercostal spaces. Periphery of the last whorl well rounded. Base short, well rounded, marked by the feeble continua- 
tions of the axial ribs, which evanesce shortly after passing the periphery, and numerous, closely spaced spiral striations. Aperture large, subquadrate, posterior angle obtuse; outer lip thin showing the external sculpture and color markings within; columella somewhat twisted, almost vertical, slightly reflected and appressed to the base for the posterior third of its length; parietal wall covered with a thin callus.

The type, Cat. No. 362146, U.S.N.M., comes from Shuyak Strait, Afognak Island, Alaska. It has nine postnuclear whorls and measures, length, $8.3 \mathrm{~mm}$; diameter, $2.2 \mathrm{~mm}$. This species is a member of the Turbonilla (Pyrgolampros) halia Dall and Bartsch group. It differs from the other known members by its coloration and flattened whorls, as well as by its size.

TURBONILLA (PYRGOLAMPROS) ILFA, new species

Plate 1, fig. 1

Shell very large. Nuclear whorls decollated. The eight and a quarter turns remaining narrowly shouldered at the summit, slightly rounded in the middle, somewhat contracted toward the base, marked by strong, well-rounded axial ribs, which are closely spaced on the early whorls, rather distantly on the middle whorls, and again closely placed on the last turn, where they become somewhat enfeebled. Of these ribs, which are almost vertical, 22 occur upon the first of the remaining turns, 24 upon the second to sixth, 26 upon the seventh and 30 upon the last. The spaces between the ribs are strongly impressed and almost as wide as the ribs on the first two turns. On the next four they are decidedly wider than the ribs, while on the next to the last they again equal the ribs and on the last they are narrower. The entire surface of the spire is marked, in addition, by fine spiral striations. Periphery of the last whorl well rounded. Base moderately long, well rounded, marked by the feeble continuations of the axial ribs and the fine microscopic spiral striations. Aperture oval; posterior angle acute; outer lip thin; inner lip somewhat sinuous, reflected over, but not appressed to the base; parietal wall covered by a thick callus.

The type, Cat. No. 340819, U.S.N.M., was collected by A. G. Smith at San Pedro, Calif. It has eight and a quarter whorls and measures, length, $12.5 \mathrm{~mm}$.; diameter, $4 \mathrm{~mm}$. This is the largest of the known West American Pyrgolampros.

TURBONILLA (PYRGOLAMPROS) SHUYAKENSIS, new species

Plate 2, fig. 1

Shell broadly conic, stout, flesh colored, with a broad band of chestnut brown encircling the periphery. This band extends almost 
as far anterior to the periphery as it does upon the base. Nuclear whorls decollated. Postnuclear whorls rather inflated, appressed at the summit, slightly rounded near the summit and the periphery and somewhat flattened in the middle, marked by very strong, slightly protractively curved, rounded axial ribs, of which 16 occur upon the first four of the remaining turns, and 18 upon the rest. The intercostal spaces, which are about as broad as the ribs, are deeply impressed. In addition to the strong axial ribs, the whorls are marked by fine incremental lines which are apparent in both intercostal spaces and on the ribs; they are also marked by rather strong, closely spaced spiral striations. Suture strongly impressed, constricting the whorls. Periphery angulated. Base short, slightly inflated, well rounded, marked by the very feeble continuations of the axial ribs, which evanesce shortly after passing the periphery, numerous lines of growth, and closely spaced, strong spiral striations. Aperture rather large, broadly oval, posterior angle obtuse; outer lip thin, showing the external markings as well as the color bands within; columella slender, slightly curved, and slightly reflected over the base to which it is appressed for the posterior half of its length.

The type, Cat. No. 362144, U.S.N.M., comes from Shuyak Strait, Afognak Island, Alaska. It has six and one-half whorls, and measures, length, $6.3 \mathrm{~mm}$.; diameter, $2.4 \mathrm{~mm}$.

This species is nearest related to Turbonilla (Pyrgolampros) newcombei Dall and Bartsch, which is known from British Columbia and Washington. It differs from the latter in being in every way more robust and in having the whorls more inflated.

TURBONILLA (PYRGOLAMPROS) MIDDENDORFFI, new species

Plate 2, fig. 2

Shell elongate-conic, flesh colored, excepting a broad band of bright chestnut brown which extends over the periphery and considerably anterior and posterior to this. Nuclear whorls two and onehalf, forming a depressed helicoid spire, the axis of which is almost at right angles to that of the succeeding turns, in the first of which the nuclear spire is about one-sixth immersed. Postnuclear whorls rather high, appressed at the summit, marked by broad, low, rather closely spaced, almost vertical axial ribs, which are very feebly expressed on the early turns. Of these ribs there are 18 on the third, 20 on the fourth and fifth, 22 on the sixth, and 24 on the last whorl. The spaces separating the ribs are only about one-half as wide as the ribs. In addition to the axial sculpture the whorls are marked by numerous, closely spaced, spiral striations. Suture moderately constricted. Periphery of the last whorl somewhat inflated. Base moderately long, inflated, marked by the feeble continuations of 
the axial ribs, which evanesce shortly after passing the periphery, and numerous, closely spaced spiral striations. Aperture rather large, posterior angle acute; outer lip thin, showing the external markings and color band within; columella slender, somewhat sinuous, slightly reflected over the base to which the posterior third is adnate; parietal wall covered by a thin callus.

The type, Cat. No. 362147, U.S.N.M., has seven and one-half postnuclear whorls and measures, length, $6.4 \mathrm{~mm}$; diameter, $2.0 \mathrm{~mm}$. It comes from Shuyak, Afognak Island, Alaska.

TURBONILLA (PYRGOLAMPROS) EYERDAMI, new species

Plate 2, fig. 12

Shell large, elongate-conic, golden yellow, with a moderately broad band of pale chestnut brown at the periphery. Nuclear whorls decollated. Postnuclear whorls appressed at the summit which is narrowly shouldered, flattened in the middle, moderately constricted at the suture, marked by rather strong, regular and regularly spaced, axial ribs, which are slightly protractively slanting on the early turns, vertical in the middle, and slightly retractively slanting on the last whorl. Twenty-two of these ribs occur upon the first to the third turns, 20 upon the fourth to the seventh, 18 upon the eighth, 22 upon the ninth, and 30 upon the last whorl. These ribs are about as wide as the spaces that separate them. The ribs and the intercostal spaces are marked by numerous, closely spaced spiral striations. Suture moderately constricted. Periphery of the last whorl inflated, well rounded. Base short, somewhat inflated, well rounded, marked by the feeble continuations of the axial riblets, which evanesce shortly after passing the periphery, and numerous lines of growth and closely spaced spiral striations. Aperture oval, posterior angle acute, outer lips thin, showing the external sculpture and the color markings within; columella slightly curved, reflected over and appressed to the base for half of its length; parietal wall covered by a thin callus.

The type, Cat. No. 362145, U.S.N.M., comes from Shuyak Strait, Afognak Island, Alaska. It has lost the nucleus. The $101 / 2$ postnuclear whorls measure, length, $10.5 \mathrm{~mm}$; d diameter, $2.7 \mathrm{~mm}$. This is a member of the Turbonilla (Pyrgolampros) hatia Dall and Bartsch group. It is not particularly closely related to any of the described species.

\section{TURBONILLA (PYRGISCUS) DELMONTENSIS Bartsch}

Plate 2, fig. 11

Shell elongate conic, golden brown, with the incised spiral lines edged with red. Nuclear whorls decollated. Postnuclear whorls 20441-27-2 
moderately rounded, narrowly shouldered at the summit, crossed by strong, slightly protractively slanting axial ribs, of which 14 occur upon the fourth and fifth of the remaining turns, 16 upon the sixth, 18 upon the seventh, 22 upon the eighth, and 28 upon the last whorl, upon which they are somewhat enfeebled and less regularly developed and spaced. The intercostal spaces are about twice as wide as the ribs and are crossed by six equally spaced incised spiral lines, of which the second is about three times as wide as the first, third, and fourth, while the fifth and sixth have about double the width of the narrow ones. Suture strongly constricted. Periphery of the last whorl well rounded, somewhat inflated. Base, short, moderately rounded, marked by somewhat irregularly spaced and irregularly developed fine spiral lines, of which there are more than 15. The exact number can not be determined on account of the erosion of the base. Aperture short, almost subquadrate; posterior angle obtuse; outer lip thin, showing the external sculpture within; inner lip almost vertical, reflected over and appressed to the base for almost half its length.

The type, Cat. No. 340818, U.S.N.M., was dredged by A. G. Smith in 10 fathoms off Del Monte, California. It has nine postnuclear whorls and measures, length, $9.7 \mathrm{~mm}$; diameter, $2.7 \mathrm{~mm}$. This species is nearest related to Turbonilla (Pyrgiscus) auricoma Carpenter and Turbonilla (Pyrgiscus) castanea Keep.

TURBONILLA (MORMULA) ENNA, new species

Plate 2, fig. 8

Shell elongate-conic, pale brown. Nuclear whorls decollated. Postnuclear whorls marked by very slightly restractively slanting, low, poorly developed, axial ribs which are a little broader than the spaces that separate them. Of these ribs, 18 occur upon the second, 22 upon the third and fourth, 24 upon the fifth and sixth, 26 upon the seventh, while upon the remaining turns they become more irregular and more numerous and ill-defined. In addition to this the whorls are marked by five spiral lines of pits in the intercosaal spaces which extend up on the sides of the ribs but scarcely cross them. These pits are a little narrower than the spaces that separate them. There are also at irregular intervals indications of varices. Aperture moderately large, oval, posterior angle obtuse; outer lip fractured, showing six strong spiral folds within, of which three are anterior and three posterior to the periphery; columella slightly expanded and reflected over the umbilicus; parietal wall covered by a rather thick callus.

The type, Cat. No. 362440, U.S.N.M., was collected by Dr. R. H. Tremper, in 6 fathoms, off Dead Mans Island, San Pedro, California, 
It has almost nine whorls remaining and measures, length, $11.6 \mathrm{~mm}$., diameter, $2.8 \mathrm{~mm}$.

TURBONILLA (MORMULA) CLEMENTINA, new speeies

Plate 2, figs. 9, 10

Shell broadly elongate-conic, chestnut brown. Nuclear whorls a little more than two, forming a depressed helicoid spire, the axis of which is at right angles to that of the succeeding turns, in the first of which the nuclear spire is about one-fifth immersed. The nuclear whorls project slightly beyond the left outline of the postnuclear spire. First postnuclear whorl well rounded, the succeeding five somewhat shouldered, about one-third the distance between the summit and the suture, anterior to the summit, while the last three are slighly rounded and rendered slightly concave below the somewhat excurved summit. The whorls are marked by slightly protractive axial ribs, which are strong on the early whorls and become enfeebled on the later turns. Of these ribs, 24 occur upon the first, 20 upon the second, 18 upon the third, 20 upon the fourth and fifth, 24 upon the sixth, 26 upon the seventh, 30 upon the eighth, and 34 upon the last turn. The spaces which separate these ribs are a little narrower than the ribs on the early turns, and about equal to the ribs on the last turn. In addition to the axial ribs the whorls are marked by six strong, incised spiral lines, which almost equally divide the posterior three-fourths of the whorls. The space between the summit and the first strongly incised pit is marked by five fine incised spiral lines, while the space between the fourth and fifth pit is also divided by a fine spiral line, which is a little nearer the fourth pit than the fifth. Sutures rendered rather conspicuous by the very narrowly shouldered summit of the whorls. Periphery of the last turn well rounded. Base short, well rounded, marked by 15 incised spiral lines, which gradually diminish in spacing and strength from the periphery to the umbilicus. The six at the umbilical region are very fine and very closely crowded. The rest increase regularly in size and spacing, excepting the fourth anterior to the periphery, which is much finer than the third and fifth. Aperture subquadrate; posterior angle obtuse; outer lip thin; inner lip almost vertical, reflected over and appressed posteriorly for about one-third of its distance to the base; parietal wall covered by a thin callus.

The type, Cat. No. 340933, U.S.N.M., comes from San Clemente Island, California. It has nine and a half whorls and measures length, $7.6 \mathrm{~mm}$.; diameter, $2.3 \mathrm{~mm}$. This species is nearest related to Turbonilla (Pyrgolampros) dora Bartsch. 
ODOSTOMIA (SALASSIA) OENOA, new species

Plate 2, fig. 3

Shell rather large, conic, grayish white. Nuclear whorls decollated. Postnuclear whorls rather high between the summit and the periphery, slopingly shouldered at the summit, marked by 24 somewhat retractively slanting, axial riblets which are separated by shallow intercostal spaces, the latter being a little narrower than the riblets. These riblets extend from the summit to the periphery while from the periphery basally they gradually evanesce. Suture rather strongly constricted. Base moderately long, well rounded. Aperture oval; posterior angle obtuse; columella provided with a strong oblique fold which is situated a little anterior to the insertion of the columella; parietal wall covered by a rather thick callus.

The type, Cat. No. 362441, U.S.N.M., was collected by Dr. R. H. Tremper in 6 fathoms off Dead Mans Island, San Pedro, California. It has almost seven whorls and measures, length $7 \mathrm{~mm}$., diameter, $2.1 \mathrm{~mm}$.

ODOSTOMIA (CHRYSALLIDA) FIA, new species

Plate 3 , fig. 8

Shell elongate-ovate, cream-yellow. Nuclear whorls deeply immersed in the first of the postnuclear turns above which the tilted edge of the last volution only projects. Postnuclear whorls strongly shouldered at the summit, and decidedly constricted at the suture, moderately rounded, marked by three strongly tuberculated spiral ridges and a fourth smooth one between the summit and the suture. These ridges are crossed by strong, somewhat retractively slanting axial ribs, of which 18 occur upon the second, 20 upon the third, and 18 upon the penultimate turn. The junction of the spiral cords and axial ribs form strong nodules which are almost hemispherical, while the spaces inclosed between them form deep rounded pits. The space between the third and the fourth, or smooth spiral cord, is crossed by fine threadlike axial riblets. Suture deeply channeled. Periphery of the last whorl strongly rounded. Base rather long, well rounded, marked by six strong slightly flattened spiral cords which grow successively weaker from the periphery toward the tip of the base. The spaces separating these cords also grow consecutively a little less in width, and are crossed by numerous fine threadlike axial riblets. Aperture rather large, effuse anteriorly; posterior angle obtuse; outer lip rendered sinuous by the external sculpture; inner lip reflected and appressed to the base for almost its entire length, provided with a moderately strong fold at its insertion; parietal wall covered with a thin callus. 
The type, Cat. No. 363780, U.S.N.M., was collected by C. R. Orcutt in Todos Santos Bay. It has four and one-half whorls and measures, length, $3 \mathrm{~mm}$., diameter, $1.5 \mathrm{~mm}$.

\section{ODOSTOMIA (CHRYSALLIDA) ERA, new species}

Plate 3, fig. 9

Shell elongate-conic, semitransluscent, bluish white. Nuclear whorls decollated. Postnuclear whorls narrowly shouldered at the summit, slightly constricted at the suture, marked by strong slightly protractively slanting axial ribs, of which 16 occur upon the second and third, 18 upon the fourth to sixth, and 22 upon the last. These ribs are a little narrower than the spaces that separate them. They are crossed by six spiral cords, of which the first is at the summit. This is rather weak, the one below the summit being the strongest, and the next four are weaker and of about the same strength and spacing. The spiral cords render the ribs slightly nodulose at their junction, while the spaces inclosed between them are rather deep pits of which those between the summit and the first spiral cord below it have their long axis parallel with the axial ribs, while those between the first and second are rounded. The rest are slightly oblong, having their long axis parallel with the spiral cords. Suture slightly constricted. Periphery of the last whorl well rounded. Base moderately long, well rounded, marked by 11 strong broad spiral cords which are separated by narrow channels. These cords grow successively weaker from the periphery toward the tip of the base. Aperture somewhat irregular effuse anteriorly; posterior angle acute; outer lip thin, showing the external sculpture within by transmitted light; inner lip twisted, reflected over and appressed to the base for almost its entire length, provided with a moderately strong fold at its insertion; parietal wall covered by a rather thick callus.

The type, Cat. No. 217931, U.S.N.M., was collected by C. R. Orcutt in Magdalena Bay. It has seven and one half whorls having lost the nucleus, and measures, length, $4.1 \mathrm{~mm}$.; diameter, $1.4 \mathrm{~mm}$.

ODOSTOMIA (CHRYSALLIDA) CUMSHEWAENSIS Bartsch

Plate 3, fig. 10

Odostomia (Chrysallida) cumshewaensis BARTsch, Proc. Biol. Soc. of Wash., vol, 34, 1921, p. 34.

Shell broadly elongate-conic, milk-white, nuclear whorls at least two, obliquely immersed in the first of the postnuclear whorls, above which about two-thirds of the nuclear spire projects. Postnuclear whorls strongly rounded, constricted at the periphery, marked by strong, retractively slanting axial ribs, of which 16 occur upon the 
first, 18 upon the second, 22 upon the third and the penultimate turn. These ribs are crossed by four strong spiral cords which are a little wider than the ribs and render the axial ribs tuberculated, the first row of tubercles at the summit being decidedly smaller than the two that succeed it. All three of these have the tubercles strongly, evenly rounded. The fourth immediately above the periphery, however, has the spiral cord stronger than the axial ribs, and appears as an almost uninterrupted cord with feebler tubercles. The pits inclosed between the ribs and spiral cords are strongly impressed and rounded. Suture strongly constricted, a part of the first basal cord showing at the suture of the last two turns. Periphery well rounded, marked by a strong spiral cord. Base moderately long, marked by five spiral cords on the anterior three-fourths, which become succeedingly narrower and feebler, the last two being indicated merely by the incised lines that separate them. The anterior fourth of the base is smooth, excepting incremental lines. The spaces between the spiral cords on the base are crossed by fine axial threads. Aperture very broadly oval; posterior angle obtuse; outer lip thin, showing the external sculpture within, inner lip strongly curved, reflected over and appressed to the base, a very narrow chink remaining behind the lip, indicating a very slight umbilicus; parietal wall covered by a thick callus.

The type, Cat. No. 340860, U.S.N.M., was collected by Mrs. Oldroyd at Cumshewa Inlet, British Columbia. It has five postnuclear whorls and measures, length, $2.7 \mathrm{~mm}$; diameter, $1.2 \mathrm{~mm}$.

This species suggests Odostomia (Chrysallida) astricta Dall and Bartsch from Monterey, but differs from it in being more conic, with the whorls more rounded and having the base shorter and more rounded, as well as in minor details of sculpture.

ODOSTOMIA (CHRYSALLIDA) TREMPERI, new species

Plate 3, fig. 1

Shell very elongate-conic, bluish white. Nuclear whorls at least two, smooth, forming a depressed helicoid spire, the axis of which is obliquely immersed in the first of the succeeding turns above which a little less than half the nuclear spire projects. Postnuclear whorls marked by rather strong, retractively slanting, axial ribs which are a little broader than the spaces that separate them. Of these ribs 14 occur upon the first, 16 upon the second to fourth, 18 upon the fifth and last turns. In addition to this the whorls are marked by four spiral cords which render the junction with the axial ribs tuberculated. The tubercules are rounded on the middle whorls and slightly elongated on the last turn, the elongation corresponding with the spiral sculpture. The spaces inclosed between the 
axial ribs and the spiral cords are deeply impressed, rounded pits. Suture strongly constricted, channeled. Periphery of the last whorl marked by a rather broad channel. Base rather long, marked by eight spiral cords of which the first two, near the periphery, are much stronger than the rest, the others becoming successively weaker. In addition to this the deep channels between the spiral cords are crossed by numerous, slender, axial threads which give them a finely ribbed appearance. Aperture elongate-oval; decidedly angulated anteriorly; posterior angle acute; outer lip thin showing the external sculpture within, and sinuous at the edge; columella twisted, provided with a rather oblique fold a little anterior to its insertion; parietal wall covered by a rather thick callus.

The type, Cat. No. 362446, U.S.N.M., was collected by Dr. R. H. Tremper on rocks at San Clemente Island, California. It has six and one-half postnuclear whorls and measures: Length $3.7 \mathrm{~mm}$.; diameter, $1.2 \mathrm{~mm}$.

A topotype of this species is in Doctor Tremper's collection.

ODOSTOMIA (CHRYSALLIDA) CLEMENTENSIS, new species

Plate 3, fig. 2

Shell very broadly conic, bluish white. Nuclear whorls decollated. Postnuclear whorls increasing rapidly in size, marked by poorly developed, axial ribs which are strongest near the summit, but evanesce before reaching the periphery. Of these 20 occur upon all the whorls. These ribs are a little wider than the spaces that separate them. In addition to these ribs the whorls are marked by five spiral cords between the summit and periphery, of which the first three are narrow and of about equal width and occupy the posterior half of the turns. These render the axial ribs tuberculate, the tubercles being elongate, the elongation corresponding with the spiral sculpture. The anterior two spiral cords are much broader. The posterior of these is feebly tuberculate, while the anterior is smooth. The spaces separating the spiral cords on the spire are of the same width, and the spaces inclosed between the axial ribs and spiral cords are narrow elongated pits, the long axes of which coincide with the spiral sculpture. These spiral pits pass up on the sides of the ribs and usually cross them. The first supraperipheral incised spiral line not being interrupted by ribs forms a continuous pitted element. Periphery of the last whorl well rounded, marked by a narrow, deeply incised channel which is also crossed by fine axial threads that render it pitted. Base well rounded, marked by 13 spiral cords, of which the anterior 3 are very feeble, while the rest are very regular in size and spacing, becoming successively a little more slender from the periphery anteriorly. The spaces that 
separate these cords are almost as wide as the cords and are marked by slender axial threads which give to the spiral grooves a strongly pitted appearance. Aperture large; posterior angle obtuse; somewhat channeled at the junction of the columella and basal wall and decidedly flaring at the junction of the outer lip and basal lip; outer lip thin, showing the external sculpture within by the transmitted light, sinuous at the edge; columella very stout, rather evenly curved, provided with an oblique fold a little anterior to its insertion; parietal wall glazed with a thin callus.

The type, Cat. No. 362447, U.S.N.M., was collected by Dr. R. H. Tremper on rocks at San Clemente Island, California. It has a little more than four postnuclear whorls, having lost the nuclear turns, and measures, length $3.2 \mathrm{~mm}$.; diameter, $1.9 \mathrm{~mm}$.

ODOSTOMIA (CHRYSALLIDA) CHACEI, new species

Plate 3, fig. 3

Shell elongate-ovate, bluish white. Nuclear whorls two and onehalf, well rounded, forming a depressed helicoid spire which is about one-half obliquely immersed in the first of the succeeding turns. The tilted edge of the last volution shows four rather strong spiral cords. Postnuclear whorls stout, separated by a profoundly channeled suture, marked by exceedingly strong axial ribs which on all but the last whorls are slightly protractive; on the latter they are almost vertical. Of these ribs 16 occur upon the second and third and 18 upon the penultimate turn. The intercostal spaces are about as wide as the ribs. In addition to the axial sculpture the whorls are marked by four strong spiral cords which render their junction with the axial ribs strongly tuberculated. The tubercles are almost hemispherical, sloping only very slightly, a little more abruptly posteriorly than anteriorly. The spaces inclosed between the axial ribs and the spiral cords are well-rounded profound pits. The summit of the whorls is tabulated. The summits of the strong ribs render the suture slightly sinuate. Periphery of the last whorl marked by a rather strong spiral cord. Base moderately long, well rounded, marked by five spiral cords which become slightly closer spaced from the peripheral cord anteriorly and also decidedly progressively enfeebled in the same direction. The broad spaces that separate the spiral cords are marked by numerous, slender, axial threads. Aperture oval; posterior angle obtuse; outer lip thin, showing the external sculpture within by transmitted light; inner lip slightly curved, appressed to the suceeding whorl for two-thirds of its length, the anterior third only being free; parietal wall covered with a thick callus. 
The type, Cat. No. 361626, U.S.N.M., was collected by E. P. Chace, at Cayucos, California. It has five postnuclear whorls and measures, altitude, $2.9 \mathrm{~mm}$; diameter, $1.8 \mathrm{~mm}$.

\section{ODOSTOMIA (CHRYSALLIDA) CATALINENSIS, new species}

Plate 3, fig. 4

Shell minute, bluish white, semitranslucent. Nuclear whorls deeply obliquely immersed in the first postnuclear turn, above which the tilted edge of the last turn only projects. Postnuclear whorls moderately rounded, marked by four strong spiral cords which are much wider than the spaces that separate them. Of these the first is at the summit. The axial sculpture is decidedly reduced on the first turn, becoming stronger on the second, while on the third there are 18 axial ribs which equal the spiral cords in strength. The junction of the axial ribs and spiral cords here form strong tubercles on the anterior three spiral cords, while the fourth is only slightly tuberculated. On the last whorl the axial ribs are very irregular and enfeebled. Here the axial sculpture consists chiefly of lines of growth, which are particularly conspicuous in the grooves between the spiral cords, where they appear as slender riblets. Particularly is this true in the groove at the periphery. Periphery well rounded. Base moderately long, well rounded, marked by seven spiral cords which grow successively narrower from the periphery toward the base, the last one at the base being a little wider than those immediately preceding it. Aperture oval, somewhat effuse anteriorly; posterior angle obtuse; outer lip thin, showing the external markings within by transmitted light; columella, slightly oblique, strongly reflected and appressed to the base, leaving only a very small chink at the umbilical area, and provided with a strong oblique fold at its insertion; parietal wall covered with a moderately thick callus.

The type, Cat. No. 347989, U.S.N.M., was collected by A. M. Strong, on Abalone at Catalina Island, California. It has four and one-half postnuclear whorls and measures, length, $3.1 \mathrm{~mm}$.; diameter, $1.6 \mathrm{~mm}$.

Twenty-four additional specimens from the same locality are in the Museum collection as Cat. No. 347990.

More than a hundred additional specimens from the same locality are in Mr. Strong's collection.

ODOSTOMIA (EVALEA) BACHIA, new species

Plate 2, fig. 7

Shell very regularly elongate ovate, bluish white. Nuclear whorls deeply obliquely immersed in the first of the postnuclear turns above which a small portion of the tilted edge of the last turn only pro-

$20441-27-3$ 
jects, which gives to the shell a decidedly truncated appearance. Postnuclear whorls rather high between the summit and the suture very slightly rounded, appressed at the summit and very slightly contracted at the periphery, marked by very fine lines of growth and numerous, closely spaced, microscopic spiral striations. This sculpture is characteristic for the early whorls as well as the last. Suture slightly constricted. Periphery of the last whorl strongly inflated, rather obtusely angulated. Base short, strongly rounded, narrowly umbilicated, marked like the spire. Aperture broadly oval; posterior angle obtuse; outer lip thin; inner lip slightly curved, reflected over and appressed to the base and provided with an oblique fold a little anterior to its insertion; parietal wall covered with a thick callus.

The type, Cat. No. 362450 , U.S.N.M., was collected by Dr. R. H. Tremper on rocks at San Clemente Island, California. It has five and one-half whorls and measures, length, $3.6 \mathrm{~mm}$.; diameter, $1.6 \mathrm{~mm}$.

Cat. No. 362451, U.S.N.M., contains a topotype, and three additional topotypes are in Doctor Tremper's collection.

ODOSTOMIA (EVALEA) EYERDAMI, new species

Plate 4, fig. 1

Shell small, very elongate-ovate, bluish white. Nuclear whorls deeply obliquely immersed in the first of the succeeding turns above which the tilted edge of the last volution only projects. Postnuclear whorls high, moderately rounded, very slightly shouldered at the summit, marked by moderately strong, equal, and equally spaced spiral striations which have about the same strength on all the whorls. Periphery somewhat inflated, well rounded. Base slightly prolonged, well rounded, marked like the spire by lines of growth and spiral striations. Aperture elongate-ovate, protracted at the junction of the base and columella; posterior angle acute; outer lip thin; columella slightly oblique, almost straight, slightly reflected and appressed to the base for about half of its length; parietal wall covered with a thin callus.

The type, Cat. No. 362149, U.S.N.M., comes from. Shuyak Strait, Afognak Island, Alaska. It has five postnuclear whorls and measures, length, $4.3 \mathrm{~mm}$.; diameter, $2.0 \mathrm{~mm}$.

This species is nearest related to Odostomia (Evalea) stephensi Dall and Bartsch, from which it differs in being constantly, in every way, smaller.

Cat. No. 362150 , U.S.N.M., contains an additional specimen from the type locality, while five are in the collection of Walter J. Eyerdam. 
ODOSTOMIA (EVALEA) WHITEI, new species

Plate 4, fig. 3

Shell very small, elongate-ovate, bluish white. Nuclear whorls smooth, deeply obliquely immersed in the first of the postnuclear turns above which the tilted edge of the last volution only projects. The nuclear spire is so obliquely placed that it gives the apex of the shell a truncated appearance. Postnuclear whorls very slightly rounded, not appressed at the summit, marked by rather strong, and deeply incised spiral lines; one a little heavier than the rest is situated a little below the summit and gives to this the appearance of being slightly keeled. In addition to this sculpture the whorls are marked by rather coarse lines of growth. Periphery of the last whorl angulated. Base short, well rounded, not umbilicated, marked by the continuation of the axial ribs and incised spiral lines which equal those on the spire in strength. Aperture pear-shaped; posterior angle acute; outer lip thin; columella slightly curved, reflected over and appressed to the base for its posterior two-thirds, and provided with a strong, oblique fold opposite the umbilical chink; parietal wall covered with a heavy callus.

The type, Cat. No. 362545, U.S.N.M., was collected by A. M. Strong at Point Firmin, California. It has 4.8 whorls and measures: Length, $2.2 \mathrm{~mm}$; d diameter, $1.2 \mathrm{~mm}$.

A topotype is in Mr. Strong's collection.

ODOSTOMIA (EVALEA) STRONGI, new species

Plate 4, fig. 4

Shell small, elongate-ovate, pale yellow, translucent. Nuclear whorls deeply obliquely immersed in the first postnuclear whorl, only half of the last turn showing, which is well rounded and smooth. The early postnuclear whorls moderately rounded, marked by strong spiral grooves which separate the whorl into equal cords, of which 10 occur on the second whorl in the type. On the third whorl these cords become very much enfeebled and on the last they are entirely obsolete. On the last whorl the incremental lines are more conspicuous than on the preceding turns, probably largely due to the absence of spiral sculpture. Suture well inpressed. The portion at the summit of the shell appressed to the preceding turn appears as an opaque band. Periphery well rounded. Base rather long, well rounded, not umbilicated. Aperture elongate oval; outer lip thin, rather sigmoid; inner lip thin, reflected over and appressed to the base for three-fourths of its length, the anterior portion only 
being free, provided with a fold at the insertion of the columella; parietal wall covered by a thin callus.

The type, Cat. No. 347804, U.S.N.M., was taken from Abalone at Catalina Island by A. M. Strong. It has almost four postnuclear whorls and measures, length, $3.5 \mathrm{~mm}$.; diameter, $1.8 \mathrm{~mm}$.

Cat. No. 347805 , U.S.N.M., contains 10 additional specimens of various ages from the same gathering, while 63 from the same lot, of different ages, are in Mr. Strong's collection.

\section{ODOSTOMIA (AMAURA) SANJUANENSIS Bartsch}

Plate 2, fig. 6

Odosomia (Amaura) sanjuanensis Bartsch, Journ. Wash. Acad. Sci., vol. 10, 1920, No. 20 , p. 571.

Shell elongate-ovate, wax yellow. Nuclear whorls decollated. Postnuclear whorls narrowly tabulatedly shouldered, moderately rounded, marked by regular retractively slanting lines of growth and fine spiral striations, which give to the surface a cloth-like texture when subjected to high magnification. In addition to this sculpture, the surface of the shell is marked by strong incremental lines and more or less irregular and irregularly distributed spiral threads, which produce a malleated pattern. Suture strongly marked Periphery of the last whorl well rounded. Base moderately long, well rounded, marked like the spire. Aperture obliquely ovate; posterior angle obtuse; outer lip thin; inner lip very obliquely retractively slanting, somewhat flexuouse and provided with a strong fold at its insertion; parietal wall covered by a thin callus.

The type, Cat. No. 334491, U.S.N.M., was collected by Dr. C. C. Engberg near San Juan Island, Gulf of Georgia. It has five and onehalf whorls and measures, altitude, $7.2 \mathrm{~mm}$; diameter, $3.5 \mathrm{~mm}$. Another specimen from the same locality is in Doctor Engberg's collection.

Cat. No. 340880, U.S.N.M., contains four specimens collected by Doctor Engberg at Olga, Washington. Cat. No. 340881, U.S.N.M., contains five specimens collected by Doctor Engberg at Washington. Fifteen more specimens are in the Engberg collection. Cat. No. 347293, U.S.N.M., contains 50 specimens collected by Doctor Engberg at Sinclair Island, Washington. Many more from the same station are in Doctor Engberg's collection.

ODOSTOMIA (AMAURA) WASHINGTONA, new species

Plate 4, fig. 10

Shell rather large, turreted, broadly elongate-conic. Nuclear whorls decollated. Postnuclear whorls broadly, tabulatedly shoul- 
dered at the summit, rather high between the angle at the summit and the suture, marked by rather coarse incremental lines which frequently show heavy erosion marks; in fact, the early whorls are badly eroded. In addition to this, the whorls are marked by fine spiral striations. Suture rendered conspicuous by the tabulated shoulder. Periphery strongly rounded. Base moderately long, somewhat inflated, strongly rounded, marked by the lines of growth and the fine spiral sculpture characteristic of the spire. There is a slight umbilical chink but not a perforation. Aperture rather large, oval, posterior angle obtuse; outer lip thin; columella oblique, slightly expanded and reflected, and provided with a strong oblique fold at its insertion; parietal wall covered with a thin callus.

The type, Cat. No. 334490, U.S.N.M., was collected by Dr. C. C. Engberg off San Juan Island, Gulf of Georgia, Washington. It has 6.2 postnuclear whorls, the nucleus being lost, and measures, length $8.6 \mathrm{~mm}$.; diameter, $4.2 \mathrm{~mm}$.

\section{ODOSTOMIA (AMAURA) ENGBERGI Bartsch}

Plate 5, fig. 5

Odostomia (Amaura) engbergi Bartsch, Journ. Wash. Acad. Sci., vol. 10, 1920, No. 20, pp. 570-571.

Shell elongate-ovate, yellow, a little paler toward the tip. Nuclear whorls eroded in all the specimens seen. Postnuclear whorls narrowly tabulatedly shouldered at the summit, quite strongly rounded, marked by very fine slightly slanting lines of growth and equally fine spiral striations; the combination, when viewed under the microscope, gives to the surface a clothlike texture. Suture strongly marked. Periphery of the last whorl inflated, strongly rounded. Base strongly rounded. Aperture narrowly ovate; posterior angle very obtuse; outer lip thin; inner lip short, very oblique, somewhat sinuous, reflected over the base and appressed to it except at the extreme tip, which alone is free; a strong fold is present on the inner lip a little anterior to its insertion; parietal wall covered by a thin callus.

The type, Cat. No. 334492, U.S.N.M., was collected by Dr. C. C. Engberg off San Juan Island, Gulf of Georgia. It has a little more than five whorls and measures, altitude, $7 \mathrm{~mm}$.; diameter, $3.4 \mathrm{~mm}$. Cat. No. 368783, U.S.N.M., contains three paratypes from the same source. Eight additional specimens from the same station are in Doctor Engberg's collection. 
The following additional specimens are in the collection of the United States National Museum:

\begin{tabular}{|c|c|c|c|}
\hline $\begin{array}{l}\text { U.S.N.M. } \\
\text { Cat. No. }\end{array}$ & $\begin{array}{c}\text { Number } \\
\text { of speci- } \\
\text { mens }\end{array}$ & Collector & Locality \\
\hline 340829 & 2 & Mrs. T. S. Oldroyd_... & $\begin{array}{l}\text { Roots of Eelgrass at Turn Island, } \\
\text { Puget Sound. }\end{array}$ \\
\hline 340882 & 120 & Dr. C. C. Engberg & Washington. \\
\hline $\begin{array}{l}340883 \\
340930\end{array}$ & ${ }^{2} 12$ & $\ldots$ do & $\begin{array}{l}\text { Olga, Washington. } \\
\text { Do. }\end{array}$ \\
\hline 342269 & 310 & & $\begin{array}{l}\text { Ballard Beach, Seattle, Wash- } \\
\text { ington. }\end{array}$ \\
\hline $\begin{array}{l}347292 \\
361955\end{array}$ & $\begin{array}{r}45 \\
{ }^{4} 15\end{array}$ & -...-do_ & $\begin{array}{l}\text { Friday Harbor, Washington. } \\
\text { Do. }\end{array}$ \\
\hline
\end{tabular}

1 There are a hundred more from this station in Doctor Engberg's collection.

2 There are 23 more from the same locality in Doctor Engberg's collection.

3 There are 4 more from the same locality in Doctor Engberg's collection.

' More specimens are in Doctor Engberg's collection.

\section{CERITHIOPSIS FRASERI Bartsch}

Plate 5, fig. 8

Cerithiopois fraseri Bartsch, Proc. Biol. Soe. Wash., vol. 34, 1921, pp. 34-35.

Shell elongate conic, chestnut brown. Nuclear whorls decollated. Postnuclear whorls almost flattened, marked by moderately strong, rounded, slightly retractively slanting axial ribs, of which 18 occur upon the first, 16 upon the second to fourth, 18 upon the fifth, 20 upon the sixth and seventh, 26 upon the eighth and the last whorl. Intercostal spaces about half as wide as the ribs. The spiral sculpture consists of three strong cords, of which the first, at the summit, is a little less strong on the early whorls than the other two, but on the last two whorls it equals the other two cords. The intersection of the axial ribs and the spiral cords forms strong tubercles rounded on the first cord, slightly truncated posteriorly on the median cord, and strongly rounded anteriorly and strongly truncated on the third cord posteriorly, and gently sloping anteriorly. The spaces inclosed between the axial ribs and spiral cords are well-rounded pits. Suture strongly impressed, the extreme appressed portion of the summit appearing as a slender sinuous spiral thread. Periphery of the last whorl marked by a sulcus about half as wide as that separating the median from the third cord. Base short, well rounded, marked by the feeble continuations of the axial ribs, which extend more or less threadlike over the base, and two strongly impressed spiral lines on the posterior fourth of the base. The space separating the first from the second of these spiral lines is about as wide as that separating 
the first from the peripheral sulcus. There is no spiral cord at the insertion of the columella. Aperture decidedly channeled anteriorly; posterior angle cbtuse; outer lip thin, rendered wavy at the edge by the external sculpture, which is visible through the substance of the shell; inner lip decidedly sinuous, reflected over and appressed to the columella; parietal wall provided with a thin callus.

The type, Cat. No. 340858, U.S.N.M., was collected by Mrs. Oldroyd at Clayoquot, British Columbia. It has nine and a half postnuclear whorls and measures, length, $6.5 \mathrm{~mm}$.; diameter $2.3 \mathrm{~mm}$.

I named this species for Dr. C. M. Frazer, Director of the Biological station, Nananimo, British Columbia.

Another specimen, Cat. No. 340856, U.S.N.M., was collected by Mrs. Oldroyd. It comes from Victoria, British Columbia, and Cat. No. 340857, U.S.M.N., two specimens, were likewise collected by Mrs. Oldroyd at Nanaimo, British Columbia. Additional specimens of this species are in Mrs. Oldroyd's collection.

\section{CERITHIOPSIS (CERITHIOPSINA) WILLETTI Bartsch}

Plate 5, fig. 1

Cerithiopsis (Cerithiopsina) willetti Bartsch, Proc. Biol. Soc. Wash., vol. 34, 1921, pp. 36-37.

Shell large, robust, elongate-conic, pale brown. All but the last nuclear whorl decollated. This shows, however, that the species belongs to the subgenus Cerithiopsina. Postnuclear whorls crossed by very strong, almost sublamellar, rather coarse, rounded, protractively slanting axial ribs, of which 16 occur upon the first to fifth, 18 upon the sixth, 20 upon the seventh, and 24 upon the last turn. Intercostal spaces about two-thirds as wide as the ribs. In addition to the axial ribs there are three strong spiral cords, of which the first is about as far anterior the summit of the whorls as it is distant from its median neighbor. The first of these spiral cords is a little less strongly developed on the earlier whorls than on the succeeding turns, where it almost equals the other two. The junction of the axial ribs and the spiral cords forms strong tubercles, of which those on the cord at the summit are well rounded, while those on the median cord are truncated posteriorly and slope gently anteriorly. The same is true of the suprasutural cord. On the last whorl, however, the tubercles are more elongated and the truncation at the anterior margin is less pronounced, the long axis of the tubercles coinciding with the axis of the shell. The spaces inclosed between the axial ribs and spiral cords are well-rounded pits. The summit of the whorls falls a little anterior to the peripheral cord and lets this appear as a narrow, smooth, sinuous thread in the somewhat constricted suture. Periphery of the last whorl marked by a 
strong cord, which constitutes the termination of the axial ribs. Base short and rounded, but concave at the junction with the columella. The junction of the columella and the base is marked by a slender spiral cord. Aperture broadly oval, decidedly channeled anteriorly; posterior angle obtuse; outer lip thin, rendered sinuous by the external sculpture, which is also seen within the aperture by transmitted light; inner lip reflected over and appressed to the columella.

The type, Cat. No. 268746, U.S.N.M., was collected by George Willett at Forrester Island, Alaska. It has nine postnuclear whorls and measures, length, $7.5 \mathrm{~mm}$; diameter, $2.5 \mathrm{~mm}$. Two specimens from the same collecting are registered as Cat. No. 366216, U.S.N.M. Four additional specimens from the same station are in Mr. Willett's collection. Another specimen, Cat. No. 340936, U.S.N.M., was collected by Mrs. Oldroyd at San Juan Islands.

This species suggests Cerithiopsis (Cerithiopsina) signa, but has much larger nuclear whorls and is in every way more robust than that species.

\section{CERITHIOPSIS (CERITHIOPSINA) SIGNA Bartsch}

Plate 5, fig. 4

Cerithiopsis (Cerithiopsina) signa Bartsch, Proc. Biol. Soc. Wash., vol. 34,1921 , p. 36.

Shell elongate-conic, pale brown. First half postnuclear whorl smooth, the next one and a half well rounded and marked by rather distantly spaced, almost vertical axial ribs. Postnuclear whorls appressed at the summit, marked by strong, rounded, almost vertical axial ribs, of which 18 occur upon the first, 14 upon the second to sixth, 16 upon the seventh, and 18 upon the last turn. The spiral sculpture consists of three strong, equally spaced cords, which are crossed by strong axial ribs. The intersection of the axial ribs and the spiral cords form strong tubercles, which are truncated on their posterior margin and slope gently anteriorly in all three groups. The spaces inclosed between the cords and the ribs are elongated pits which have their long axis coinciding with the spiral sculpture. In addition to this the entire surface of the spire is marked by fine axial lines of growth and closely spaced spiral striations. Suture strongly impressed. Periphery of the last whorl rendered angulated by a keel. Base short, slightly concave at the insertion of the columella, marked by fine lines of growth and very fine spiral striations, and a slender spiral thread at the insertion of the columella. Aperture subquadrate; decidedly channeled anteriorly; posterior angle obtuse; outer lip rendered sinuous by the spiral cords; inner lip sigmoid, reflected over and appressed to the columella. 
The type, Cat. No. 340826, U.S.N.M., was collected off O'Neal Island, Puget Sound. It has 10.5 whorls and measures, length, 5.5 mm.; diameter, $2.7 \mathrm{~mm}$.

The following additional specimens have been examined: Three specimens, Nanaimo, British Columbia, Cat. No. 340841, U.S.N.M.; four specimens, Port Orchard, Puget Sound, Cat. No. 133233, U.S.N.M.; seven specimens, San Juan Island, Puget Sound, Cat. No. 340934, U.S.N.M.

CERITHIOPSIS (CERITHIOPSIDELLA) ONEALENSIS Bartsch

Plate 5, fig. 2

Cerithiopsis (Cerithiopsidella) onealensis Bartsch, Proc. Biol. Soc. Wash., vol. 34, 1921, pp. 35-36.

Shell elongate-conic, pale chestnut brown. Nuclear whorls decollated in the type. In one of the three specimens of this species (Cat. No. 346649, U.S.N.M.), collected by G. Willett at Craig, Alaska, the last two nuclear whorls are present. These show slender, decidedly retractively curved, rather distantly spaced, axial riblets between which many even finer spiral threads are present. Postnuclear whorls moderately rounded, slightly overhanging, crossed by very strong, broad, rounded, slightly protractively slanting axial ribs, of which 16 occur upon the first four turns, 18 upon the fifth, and 26 upor: the last. Intercostal spaces about half as wide as the ribs. In addition to the axial ribs the whorls are crossed by three strong spiral cords, of which the one at the summit is a little less strong than the other two. The junction of the axial ribs and spiral cords forms very prominent tubercles. Those on the cord near the summit are well rounded. Those on the median cord are truncated posteriorly and almost truncated anteriorly, while those on the cord above the suture are abruptly truncated posteriorly and slope moderately, gently anteriorly. On the last whorl, where the ribs are much more crowded, the tubercles have an oblong outline, and are about equal on all three cords, their long axis coinciding with the axis of the shell. The pits inclosed by the spiral cords and axial ribs are well rounded on all the whorls. Suture strongly impressed. Periphery of the last whorl marked by a sulcus about as broad as that separating the median from the supersutural cord on the spire. Base short, well rounded, marked by feeble continuations of the axial ribs, which lend it a roughened aspect, and a single slender spiral thread, which encircles the base at the insertion of the columella. Aperture decidedly channeled anteriorly; posterior angle obtuse; outer lip thin, showing the external sculpture within, sinuous at the edge; inner lip sigmoid, reflected over and appressed to the columella. 
The type, Cat. No. 340827, U.S.N.M., was collected by Mrs. Oldroyd in 20 fathoms, off O'Neal Island, Puget Sound. It has almost seven postnuclear whorls and measures, length, $5.1 \mathrm{~mm}$; diameter $1.9 \mathrm{~mm}$.

We have seen the following additional specimens: Cat. No. 362165, U.S.N.M., six specimens, from Shuyak, Strait, Afognak Island, Alaska, collected by Walter Eyerdam; Cat. No. 342739, U.S.N.M., six specimens, collected by Dr. Carl C. Engberg at Olga, Washington. Nine additional specimens from the same locality are in Doctor Engberg's collection. Cat. No. 346649, U.S.N.M., contains three specimens collected by G. Willett at Craig, Alaska.

\section{CERITHIOPSIS (CERITHIOPSIDELLA) FIA, new species}

Plate 5, figs. 6, 7

Shell broadly conic, chestnut-brown. Nuclear whorls decollated excepting a portion of the last turn which has numerous slender distantly spaced, retractively slanting axial threads and numerous fine spiral threads in the intercostal spaces which are placed at right angles to the axial ribs. Postnuclear whorls moderately rounded, marked by almost vertical axial ribs of which 14 occur upon the first and second, 16 upon the third and fourth, 18 upon the fifth and sixth, 20 upon the seventh, and 22 upon the last turn. These ribs are about as wide as the spaces that separate them. In addition to the axial sculpture, the whorls are marked by three strong spiral cords of which the first at the summit is a little weaker than the rest. These cords render their junction with the axial ribs strongly nodulose. The nodules of the cord at the summit are rounded; those of the other two cords are truncated posteriorly and slope gently anteriorly. The pits inclosed between the axial ribs and spiral cords are almost rounded. Periphery marked by a strong spiral cord which is separated from the first supraperipheral cord by a groove about as wide as that separating that cord from the median of the spire. The groove is crossed by the continuations of the axial ribs which extend feebly over the cord and render it weakly tuberculate. Base short, well rounded, marked by four strong spiral cords which grow successively weaker from the posterior anteriorly. These are separated by grooves much narrower than the width of the cords, and they are rendered slightly tuberculated by the slender continuation of the axial ribs. Aperture subquadrate, decidedly channeled anteriorly; posterior angle obtuse; outer lip thin, showing the external sculpture within, rendered sinuous at the edge by the external sculpture; inner lip sigmoid.

The type, Cat. No. 340935 U.S.N.M., was collected by Mrs. T. S. Oldroyd at Monterey Bay, California. It has nine whorls, and 
measures, length, $7.4 \mathrm{~mm}$; diameter, $2.9 \mathrm{~mm}$. Cat. No. 363781, U.S.N.M., contains a younger specimen collected by H. N. Lowe at Laguna, California. We give a figure of this also.

\section{CERITHIOPSIS (CERITHIOPSIDELLA) SANTACRUZANA, new species}

Plate 5, fig. 3

Shell stout, very broadly conic, pale brown. Early nuclear whorls decollated, the last one and one-half marked by very slender, distantly spaced, decidely protractively slanting axial riblets, while the broad spaces between them are marked by slender raised threads which are placed at right angles to the axial riblets. Postnuclear whorls moderately rounded, marked by strong, retractively slanting axial ribs. Of these, 16 occur upon the first to fourth, 18 upon the fifth, 20 upon the sixth and seventh, and 22 upon the penultimate turn. The spaces which separate the axial ribs are about as wide as the ribs. In addition to the axial sculpture, the whorls are marked between summit and suture by three strong spiral cords, of which the first, which is at the summit, is a little weaker than the other two on all the turns but the last. The junction of the axial ribs and spiral cords form strong tubercles which are truncated posteriorly and slope more gently anteriorly. The spaces inclosed between them are roundish pits. Suture moderately impressed. Periphery of the last whorl marked by a rather strong cord. The space separating this from the cords of the spire is crossed by the continuation of the axial ribs, which extend to the cord but do not cross it, nor do they tuberculate it. Base short, moderately rounded, marked by a spiral cord which is a little less strong than the one at the periphery from which it is separated by a channel a little narrower than that separating the peripheral cord from the first supraperipheral. Aperture subquadrate, decidedly channeled anteriorly; posterior angle obtuse; outer lip rendered wavy by the external sculpture; inner lip sigmoid.

The type, Cat. No. 363785 U.S.N.M., comes from Santa Cruz, California. It has 10 whorls and measures, length, $5.9 \mathrm{~mm}$. ; diameter, $2 \mathrm{~mm}$.

\section{Alaba CATAlinensis Bartsch}

Plate 2, fig. 5

Alaba catalinensis Bartsch, Journ. Wash. Acad. Sci., vol. 10, 1920, No. 20, p. 572.

Shell elongate-conic, milk white, early whorls well rounded, the succeeding turns a little less so. All whorls polished, appressed at the summit, and marked by fine retractively slanting lines of growth. Beginning with the second turn, varicial thickenings make their appearance; these are very feeble on the early whorls, but increase 
steadily in strength until on the last turn they form decidedly raised sinuous ridges. The last whorl, too, shows well-marked malleations. Aperture oval; posterior angle obtuse; inner lip curved and reflected, but not appressed to the base; parietal wall covered by a thick callus.

The type, Cat. No. 213369, U.S.N.M., was collected by Dr. S. S. Berry in 40 fathoms, off Catalina Island, California. It has $101 / 2$ whorls and measures, length, $5.3 \mathrm{~mm}$.; diameter, $1.9 \mathrm{~mm}$. It is at once distinguished from the other two West American species by the absence of incissed spiral lines.

\section{AMPHITHALAMUS STEPHENSAE, new species}

\section{Plate 4 , fig. 5}

Shell minute, pale brown with an ashy tinge except the columellar region which is flesh colored; the early whorls when they contain the animal are much more dusky. Nuclear whorls 1.5 ; the first half smooth, the rest marked by rather distantly spaced, poorly developed, rather broad spiral lirations of which nine are present between the summit and the periphery. In addition to this, there are inconspicuous lines of growth. Postnuclear whorls strongly rounded, narrowly shouldered at the summit, the portion appressed to the preceding turn appearing through the substance of the shell as a band. Periphery with a weak keel which is truncated rather abruptly posteriorly but grades gently into the substance of the shell toward the base. Suture well marked. Base short, inflated, strongly rounded, marked by lines of growth only. There is a heavy callus at the insertion of the columella, which at its posterior termination almost forms a cord. The columella itself is very heavy and oblique. The conformation of the aperture is characteristically Amphithalmid, that is, the aperture which is oval is much contracted by having a shelf extending out from the columellar and the parietal wall toward the outer lip, contracting the aperture. This shelf forms a decided pit behind its edge. The inner and parietal lip of the aperture, therefore, are not in contact with the columellar or the parietal wall, but at some distance from it; the posterior portion of the outer lip, however, extends upward to the preceding turn, which it joins immediately below the peripheral keel as in mollusks with a normal aperture. Operc!lum thin, paucispiral.

The type, Cat. No. 348531, U.S.N.M., was collected by Mrs. C. L. Simons in Magdalena Bay, Lower California. It has four whorls, and measures, length, $1.1 \mathrm{~mm}$; greater diameter, $0.9 \mathrm{~mm}$. Cat. No. 348532 , U.S.N.M., contains an additional lot of specimens taken from kelp root in Turtle Bay by Mrs. Simons. 
This species differs from the two previously known forms, Amphithalamus inclusus Carpenter and Amphithalamus tenuis Bartsch in being much stouter than $A$. tenuis Bartsch, and in having coarser spiral threads on the early whorls, a less strong peripheral keel, and more rounded whorls than $A$. inclusus Carpenter.

\section{ALVANEA SANJUANENSIS, new species}

\section{Plate 3, fig. 7}

Shell moderately large, chestnut brown excepting the tip, which is a little paler and the extreme base which is lighter. Nuclear whorls one and a half, well rounded; the sculpture of the nuclear whorls eroded in all the shells seen except in a very small fraction of the last turn in the type, which presents a finely, somewhat wavy, spirally lirate surface. I am not quite certain whether axial threads are present or not. Postnuclear whorls strongly shouldered at the summit, strongly rounded, marked on the first turn by three strong spiral cords, which occupy the anterior half of the turn; on the second turn a fourth cord occurs a little anterior to the median line between the summit and the first strong cord, while on the next turn a fifth slender thread makes its appearance between the summit and this cord. This last cord at the summit never attains a strength as great as the third anterior to it, while the second one is fully as strong on the penultimate turn. In addition to these spiral cords the shell is marked by rather weak axial ribs, of which 24 occur upon the second, 26 upon the third, and about 32 upon the last turn; on this they are decidedly enfeebled. The junction of the axial ribs and spiral cords forms feeble nodules. The entire surface of the spire between ribs and interspaces is crossed by fine spiral and axial threads which lend it a fine clothlike texture. Suture strongly constricted. Periphery of the last whorl well rounded. Base moderately long, well rounded, marked by seven equally spaced spiral threads, of which the seventh immediately behind the inner lip is very feeble. The rest are almost as wide as the spaces that separate them. The axial ribs do not extend over the base, but the fine sculpture described for the spire is also present here. Aperture ovate; posterior angle obtuse; outer lip thin at the edge, strongly curved; inner lip strongly curved, reflected and appressed to the base except at the extreme tip; parietal wall covered by a thick callus, which renders the peritreme complete.

The type, Cat. No. 334487, U.S.N.M., was collected by Dr. C. C. Engberg at San Juan Island, Gulf of Georgia. It has five whorls and measures, altitude, $3 \mathrm{~mm}$; diameter, $1.5 \mathrm{~mm}$. Three additional specimens, Cat. No. 363777, U.S.N.M., come from the same gathering. 
Eight more specimens from the same station are in Doctor Engberg's collection. Cat. No. 342330, U.S.N.M., contains 16 specimens from Olga, Washington. Sixty more from the same station are in Doctor Engberg's collection. Cat. No. 340865, U.S.N.M., contains 20 from Washington without specific locality.

This species is nearest related to Alvania montereyensis Bartsch, but can at once be distinguished from it by its much larger size, as well as other detail characters.

ALVANIA DALLI, new species

Plate 3, fig. 6

Shell small, thin, semitranslucent, bluish white. Nuclear whorls one and one-half, strongly rounded, finely granular. Postnuclear whorls rather inflated, strongly rounded, appressed at the summit, marked by five low, rounded, not quite equal and equally spaced spiral cords, which are about as wide as the spaces that separate them, and numerous, fine lines of growth and microscopic, closely spaced, spiral striations. The incremental lines and fine spiral sculpture give to the surface of the shell a fine clothlike texture. Suture strongly constricted. Periphery of the last whorl inflated, well rounded. Base short, strongly rounded, narrowly umbilicated, marked by 14 spiral cords which become a little less strong and closer spaced anteriorly. In addition to this the base is marked by the fine sculpture referred to on the spire. Aperture subcircular, posterior angle decidedly obtuse; outer lip thin, strongly curved, showing the external sculpture within; columella slender and slightly reflected; parietal wall covered by a thick callus which renders the peritreme complete.

The type, Cat. No. 362154, U.S.N.M., comes from Shuyak Strait, Afognak Island, Alaska. It has four and one-half postnuclear whorls and the nuclear turns and measures, length $2.5 \mathrm{~mm}$., diameter, $1.3 \mathrm{~mm}$.

Cat. No. 362155, U.S.N.M., contains foar additional specimens from the type locality, while Walter J. Eyerdam's collection contains nine more.

\section{ALVANIA BURRADENSIS Bartsch}

Plate 3, fig. 5

Alvania burradensis Bartsch, Proc. Biol. Soc. Wash., vol. 34, 1921, p. 38.

Shell very broadly ovate, pale yellow. Nuclear whorls decollated in all our specimens. Postnuclear whorls strongly inflated, marked by strong, rather distantly spaced, curved and slightly protractively slanting axial ribs, of which 24 occur upon the next to the last and 22 upon the last turn. In addition to the axial ribs the whorls are crossed by six equal and equally spaced, broad spiral cords, which 
render the axial ribs obscurely nodulose at their junction. The spaces separating the spiral cords are a little less wide than the cords. Periphery of the last whorl marked by a sulcus, which is crossed by the continuation of the axial ribs, which extend partly over the base, but evanesce soon after passing the periphery. Base short, strongly rounded, marked by nine equal and equally spaced prominent spiral cords, which are a little wider than the spaces that separate them. Aperture subcircular; posterior angle obtuse; outer lip reinforced by a callus at the edge; inner lip curved and appressed to the base; parietal wall covered by a moderately thick callus.

The type, Cat. No. 340938, U.S.N.M., was collected by Mrs. Oldroyd at Burrard Inlet, British Columbia. It has four whorls remaining and measures, length, $2.2 \mathrm{~mm}$.; diameter, $2 \mathrm{~mm}$. Cat. No. 363778 , U.S.N.M., contains two specimens from the same gathering. Five additional specimens from the same station are in the Oldroyd collection.

This species is nearest related to Alvania rosana from off Santa Rosa Island. It differs from this by its less acute outline, by having the whorls more rounded, and also in other details of sculpture.

\section{? RISSOELLA CALIFORNICA, new species}

Plate 4, fig. 2

Shell small, thin, semitranslucent, bluish white, broadly ovate. Nuclear whorls smooth, scarcely differentiated from the postnuclear turns. Postnuclear whorls very strongly inflated, strongly rounded, marked by rather strong, retractively slanting, incremental lines and very feebly developed, almost obsolete spiral threads. Periphery of the last whorl inflated, strongly rounded. Base short, inflated, strongly rounded, with a rather broad, open umbilicus which is marked at its external termination by an obsolete angle. The sculpture of the base is like that of the spire. Aperture broadly oval, rather expanded at the junction of the basal and outer lips. Posterior angle acute; outer lip thin; inner lip strongly curved and expanded over the parietal wall, thus rendering the peritreme complete; the outside of the inner lip at the umbilicus is marked by strong incremental lines.

The type, Cat. No. 362453, U.S.N.M., was collected by Dr. R. H. Tremper on rocks at San Clemente Island, California. It has 4.2 whorls and measures, length $2.4 \mathrm{~mm}$.; diameter, $1.16 \mathrm{~mm}$.

I am placing this species in the genus Rissoella with some doubt, but until I will have seen anatomic material I hesitate to give it a distinct generic designation.

A topotype of this species is in Doctor Tremper's collection. 


\section{MARGARITES (LIRULARIA ?) SMITHI, new species}

Plate 4 , figs. $7,11,12$

Shell minute, rather elevatedly helicoid, white. Nuclear whorls one and a half, well rounded with a carina about one-third of the distance between the summit and the suture, anterior to the summit. Postnuclear whorls well rounded, marked by the continuation of the nuclear carina, which forms a rather strong cord and a slender cord about midway between this and the summit, and two strong cords which divide the space between the carina and the suture into equal spaces. Between these three cords a lesser one is present. From the third cord, which almost marks the periphery on the last whorl, the base curves gently to the rather open umbilicus. The base is marked by spiral cords, which increase steadily in strength from the periphery to the umbilical angle; the last five are very strongly developed. The umbilical wall appears to be free of sculpture, excepting incremental lines. The spire and base of the shell are marked by strong incremental lines, which in crossing the base, form slight riblets between the spiral cords. Aperture, oval; posterior angle, obtuse; outer lip, thin; peristome complete; operculum multispiral, horny.

The type, Cat. No. 340814, U.S.N.M., was collected in 10 fathoms off China Point, Monterey, California, by A. G. Smith. It has 2.1 postnuclear whorls and measures, altitude, $1.6 \mathrm{~mm}$.; greater diameter, $1.7 \mathrm{~mm}$.

SOLARIORBIS ARNOLDI, new species

Plate 6, figs. 7, 8, 9

Shell large, lenticular, semitranslucent, bluish white. Nuclear whorls 1.2, well rounded, smooth. Postnuclear whorls moderately rounded, almost appressed at the summit, the first marked by six interrupted lines of pits and two slender spiral striations near the summit. As the whorls progress the pits become more or less fused into incised spiral lines, of which 7 occur upon the second and 24 upon the last whorl. In addition to the spiral sculpture, the whorls are marked by slender, somewhat irregular retractively slanting axial threads. Periphery of the last whorl slightly obtusely angulated. A rather broad band immediately below the periphery is devoid of spiral sculpture. Base broadly openly umbilicated; the posterior half marked by incised spiral lines which leave the elements between them as moderately broad, flattened cords and numerous lines of growth. The latter are a little rougher at the umbilical angle than on the flattened base. The umbilicus shows all the turns within it. Aperture decidedly oblique, oval; posterior angle with a slender sinus; outer lip thin, showing the external sculpture by transmitted 
light; inner lip heavy, thickened, curved; parietal wall covered with a rather thick callus that renders the peritreme complete.

The type, Cat. No. 363784, U.S.N.M., was collected by Delos Arnold at San Pedro, California. It has three and one-half whorls and measures, length, $4 \mathrm{~mm}$; height, $1.8 \mathrm{~mm}$; greater diameter, $4.3 \mathrm{~mm}$.

VITRINELLA (DOCOMPHALA) COLUMBIANA, new species

Plate 6, figs. 1, 2, 3

Shell small, thin, depressed, helicoid, semitranslucent, bluish white. As usual in this group, the outer surface is badly worn and shows only rough eroded incremental lines which are best developed on the last portion of the last whorls where they have a decidedly retractive slant. The whorls are appressed except the last one which shows a narrow channel at the summit near its termination; moderately well rounded; the early whorls are almost flattened on the upper surface, the last one moderately well rounded. Periphery strongly rounded. Base moderately rounded, moderately, broadly, openly umbilicated, with the usual coarse notching on the columellar wall of the umbilicus. Aperture large, oblique, subcircular; peristome almost complete except for a little notch on the parietal wall; outer lip thin; the basal lip becoming thickened toward the columellar portion; the columella itself is very much thickened and slightly reflected.

The type, Cat. No. 340848, U.S.N.M., was collected by Dr. I. S. Oldroyd in Departure Bay, British Columbia. It has lost part of the nuclear whorl but probably had 3.2 turns. It measures, length, $1.5 \mathrm{~mm}$.; greater diameter, $3 \mathrm{~mm}$.; lesser diameter, $2.2 \mathrm{~mm}$.

The present species is nearest related to Vitrinella (Docomphala) stearnsi Bartsch, from which it differs by its much narrower umbilicus and more subcircular aperture, also in having the excavation on the umbilical wall much less pronounced.

VITRINELLA SMITHI, new species

Plate 4, figs. 6, 8, 9

Shell minute, pale brown. Nuclear whorls one and a half, smooth. Postnuclear whorls two, well rounded, with well-impressed suture, marked by strongly curved lines of growth only. Under surface widely, openly umbilicated, marked by lines of growth only. The last whorl strongly curved. A perture slightly oblique, subcircular; peristome thin, rendered complete by the thick callus on the parietal wall.

The type, Cat. No. 340813, U.S.N.M., was collected by A. G. Smith at Whites Point, California. It measures, altitude, $0.6 \mathrm{~mm}$.; greater diameter, $1.2 \mathrm{~mm}$.

The present species is nearest related to Vitrinella oldroydi, from which it is at once distinguished by its much smaller size. 


\section{CYCLOSTREMELLA CONCORDIA Bartsch}

Plate 6 , figs. $4,5,6$

Clclostremella concordia Bartsch, Journ, Wash. Acad. Sci., vol. 10, 1920, No. 20, p. 572 .

Shell very small, planorboid, hyaline, semitransparent. Early whorls eroded in all the specimens seen. The last two whorls curve suddenly to the deeply channeled suture on the upper surface; the rest gradually, evenly rounded. Periphery of the last whorl well rounded. Base openly umbilicated. The entire surface of the spire and base is marked by rather strong, irregularly developed incremental lines and more or less equal and equally spaced, fine spiral lirations. The intersections of these two sculptural elements give to the surface of the shell the characteristic beaded sculpture of the genus. Aperture very broadly ovate, almost subcircular, the narrower portion being at the posterior angle; peristome thin, not reflected; parietal wall covered by a thin callus. Operculum thin, corneous, paucispiral.

The type, Cat. No. 340862, U.S.N.M., was collected by Prof. Carl C. Engberg at Olga, Washington, and measures, altitude, $1 \mathrm{~mm}$.; diameter, $2 \mathrm{~mm}$. Two additional specimens from the same locality are in Professor Engberg's collection. Cat. No. 342327, U.S.N.M., contains two specimens collected at Lisabeula, Washington, by Professor Engberg. Five more specimens from this locality are in the Engberg collection. The Museum also has specimens from Friday Harbor, Washington.

This species has been known from the last-named locality under the names of Skenia and Skeniopsis planorbis Fabricius.

It is easily distinguished from its nearest neighbor, Cyclostremella california Bartsch, by its smaller size, more robust form and weaker sculpture.

\section{EXPLANATION OF PLATES}

Plate 1

Fig. 1. Turbonilla (Pyrgolampros) ilfa.

2. Aclis californica.

3. Turbonilla (Strioturbonilla) kincaidi.

4. Turbonilla (Chemnitzia) engbergi.

5. Astyris clementensis.

6. Melanella (Melanella) portlandica.

7. Turbonilla (Ptycheulimela) magdalenensis.

8. Opalia tremperi. 
Plate 2

Fra. 1. Turbonilla (Pyrgolampros) shuyakensis.

2. Turbonilla (Pyrgolampros) middendorffi.

3. Odostomia (Salassia) oenoa.

4. Turbonilla (Pyrgolampros) stelleri.

5. Alaba catalinensis.

6. Odostomia (Amaura) sanjuanensis.

7. Odostomia (Evalea) bachia.

8. Turbonilla (Mormula) enna.

9. Turbonilla (Mormula) clementina.

10. Turbonilla (Mormula) clementina, detail of intercostal sculpture.

11. Turbonilla (Pyrgiscus) delmontensis.

12. Turbonilla (Pyrgolampros) eyerdami.

\section{Plate 3}

Fig. 1. Odostomia (Chrysallida) tremperi.

2. Odostomia (Chrysallida) clementensis.

3. Odostomia (Chrysallida) chacei.

4. Odostomia (Chrysallida) catalinensis.

5. Alvania burrardensis.

6. Alvania dalli.

7. Alvania sanjuanensis.

8. Odostomia (Chrysallida) fia.

9. Odostomia (Chrysallida) era.

10. Odostomia (Chrysallida) cumshewaensis.

Plate 4

Fig. 1. Odostomia (Evalea) eyerdami.

2. ? Rissoella californica.

3. Odostomia (Evalea) whitei.

4. Odostomia (Evalea) strongi.

5. Amphithalamus stephensae.

6. Vitrinella smithi.

7. Margarites (Lirularia?) smithi.

8. Vitrinella smithi.

9. Vitrinella smithi.

10. Odostomia (Amaura) washingtona.

11. Margarites (Lirularia?) smithi.

12. Margarites (Lirularia?) smithi.

Plate 5

Fig.1. Cerithiopsis (Cerithiopsina) willetti.

2. Cerithiopsis (Cerithiopsidella) onealensis.

3. Cerithiopsis (Cerithiopsidella) santacruzana.

4. Cerithiopsis (Cerithiopsina) signa.

5. Odostomia (Amaura) engbergi.

6. Cerithiopsis (Cerithiopsidella) fia.

7. Cerithiopsis (Cerithiopsidella) fia.

8. Cerithiopsis fraseri. 


\section{Plate 6}

FrG. 1. Vitrinella (Docomphala) columbiana.

2. Vitrinella (Docomphala) columbiana.

3. Vitrinella (Docomphala) columbiana.

4. Cyclostremella concordia.

5. Cyclostremella concordia.

6. Cyclostremella concordia.

7. Solariorbis arnoldi.

8. Solariorbis arnoldi.

9. Solariorbis arnoldi. 


\section{$2 \mathrm{BHL}$ Biodiversity Heritage Library}

Bartsch, Paul. 1927. "New west American marine mollusks." Proceedings of the United States National Museum 70(2660), 1-36.

https://doi.org/10.5479/si.00963801.70-2660.1.

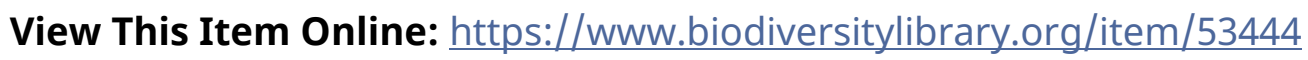

DOI: https://doi.org/10.5479/si.00963801.70-2660.1

Permalink: https://www.biodiversitylibrary.org/partpdf/52009

\section{Holding Institution}

Smithsonian Libraries

\section{Sponsored by}

Smithsonian

\section{Copyright \& Reuse}

Copyright Status: Public domain. The BHL considers that this work is no longer under copyright protection.

This document was created from content at the Biodiversity Heritage Library, the world's largest open access digital library for biodiversity literature and archives. Visit BHL at https://www.biodiversitylibrary.org. 